\title{
Foreign Direct Investment in the Mongolian Mining Sector
}

\author{
Erdenebat Mungunzul $^{1}$ and Taikoo Chang ${ }^{2 *}$ \\ ${ }^{1}$ Dept of Economics, Graduate School, Daegu University, \\ 201 Daegudaero, Chinryangup, Kyungsansi, Kyungbuk, 38453, Korea \\ ${ }^{2}$ Dept of Economics, Daegu University, \\ 201 Daegudaero, Chinryangup, Kyungsansi, Kyungbuk, 38453, Korea \\ ${ }^{1}$ Mungunzul14@gmail.com, ${ }^{2}$ tkchang1@hanmail.net
}

\begin{abstract}
Attraction to foreign investment in Mongolia's economy has become a key factor in Mongolia's development. Mongolia has a small population, especially in comparison to some other "tiger" economies. There is a large population emerging into a wealthier class, which is expected to increase consumption. Mongolia is geographically the 19th largest country in the world and has many natural resources. This paper diagnoses the Mongolian mining sector and identifies its problems, constraints, growth, and increased contributions to the national economy. The paper also addresses FDI trends in the mining sector in Mongolia in comparison to FDI in mining in developing countries and their processes, advantages, and government policies.
\end{abstract}

Keywords: Foreign Direct Investment, Mining Sector, Economic Growth, Direct and Indirect Impact

\section{Introduction}

Mongolia is a landlocked country in the heart of the Asian continent. Mining is important to the national economy of Mongolia. Mongolian geology is complex and rich in its mineral potential. Coal, copper, and gold are the principal reserves mined in Mongolia. Several gold mines are located about 110 kilometers (68 miles) north of Ulaanbaatar, the capital. Mongolia's large-scale mining projects include the Tavan Tolgoi coal mine and the Oyu Tolgoi copper and gold mine. The mining sector is the most important economic sector in Mongolia, accounting for about half of the country's gross industrial output and $40 \%$ of export revenues.

It directly employs over 12,000 people. Copper, gold, and fluorite dominate the country's mining production, which, with the exception of gold, has been fairly static, also producing limited amounts of tungsten, salt, clay, lime. Mongolia's geology has vast mineral potential. Mongolia occupies the interior portion of the Eurasian Plate and the Tuva Terrane, and in the northern region, it has over 6000 mineral showings of 80 different known minerals.

In the past few years, Mongolia has attracted foreign investors from other countries through its rich natural resources. Mining is a key factor influencing Mongolia's future development. Mongolia is located next to two of the largest economies in the world: Russia and China. Most of Mongolia's mining exports go to China (approximately 90\%).

* Corresponding Author 
This geographic situation influences the country's economy, including its exports. Mongolia is a major producer of several minerals including coal, copper, gold, zinc, and fluorspar.

With extensive reserves, it has the potential to sharply increase production. Some investors, firms, and mining/mining-related services represent one of the most important and potentially most reliable sectors for long-term investment in Mongolia. Mongolia's natural resources offer the prospect of long-term economic development for the Mongolian people. If well managed, the recent expansion of international investment in Mongolia's mining could sustain the country's economy into the $21^{\text {st }}$ century and offer a host of benefits to its society. Global mineral exploration and mining operations should respect the cultural heritage and traditions of the Mongolian people as well as the environment because the past few years have witnessed sharp increases in Mongolia's air pollution, environmental pollution, and healthcare problems.

In addition to mining, Mongolia's agriculture, textiles, and infrastructure (transportation and telecommunications) are the country's primary sectors. However, none of those sectors have attracted anywhere near the attention that natural resources have attracted. For agriculture, one of the reasons why it has not seen the same level of development as mining is because Mongolia has an extremely harsh winter every several years. This reduces the predictable cyclicality of the market, which is usually a requirement in the agricultural market across the world. In addition, Mongolia is geographically isolated, finding itself landlocked and wedged between northern China and Siberia. This presents some problems in terms of getting exports out of the country. Mongolia's unprecedented economic growth was seen in 2011-2013. During this period, Mongolia's economic growth received global attention. GDP growth was 17.3\% in 2011. It is clear that Mongolia's living standards have grown quickly, whereas the poverty rate has fallen. This may be explained by the mining boom in Mongolia, during which foreign investors were attracted to Mongolia. Other promising sectors based on Mongolia's economic development needs include infrastructure, transportation, energy, construction, health care, and environmental products and services. Fueled by the mining boom, Mongolia is one of the fastest-growing economics in the world, attracting considerable investment interest. As a result of foreign direct investment (FDI) in Mongolia in the past decade, 1,600 joint ventures and wholly foreign-owned companies from 62 countries were registered in Mongolia, with the total investment reaching \$350 million. Here China has been the largest investor (30\%), followed by South Korea (12\%), Japan (10\%) and Russia $(5 \%)$. If northeast Asia is considered in a wide sense, its FDI reaches $66 \%$, assuming the FDI from North America (the U.S. and Canada) to be about 9\% (fourth among the leading countries).

The mining tax regime is a distinct characteristic of the mining industry, including its relatively high risk, capital intensive and cyclical nature, remote location, finite life, and substantial restoration obligations. Types and levels of taxes imposed on mining enterprises have a direct bearing on their rate of return on capital. Based on general tax rules, the minimum return on investment sought by mining investors is $15 \%$ to $18 \%$ depending on country risk and other factors. Mining investors should also be able to rely on the certainty and stability of tax rules. Tax stability agreements can reduce perceived risks, which reduce financing costs and make projects more economically viable. Mongolia competes with other countries in Asia and other regions to attract investment in its capital-intensive mining sector, and therefore it is important that its tax regime be internationally competitive by embracing best practices. In assessing the international competitiveness of Mongolia's tax regime, it is helpful to undertake both qualitative and quantitative analyses of the tax regime. 


\section{The Impact of the Mining Sector on Economic Revenues}

Mongolia had the highest macroeconomic results in 2011-2013 as a result of it being the period of the mining boom in the country. The minerals industry has evolved into a truly global industry that is highly competitive, generally capital intensive, technologically complex, and risky. With a few exceptions, its development has been dependent on and shaped by competitive global commodity markets, geological mineral endowments, and national legal, regulatory, and fiscal conditions. The industry has been increasingly influenced by a limited number of well-financed and technologically advanced international mining companies. These companies are highly selective, risk averse, and sensitive to changes in the investment climate.

Mining sector growth can have both positive and negative impacts on economic development. Growth in the mining sector should generally increase GDP and GNP as the per-unit return on labor and capital (including that which is domestically owned) and the supply of natural resources increase. Capital and labor have to be imported to compensate for domestic shortages, and therefore their impact on GDP is larger than otherwise. To determine the impact of the mining sector on industrial output, export earnings, fiscal receipts, and GDP growth, a series of projections has to be made for each of the mining operations and proposed projects in the sector. These are based on commodity price distributions, cash flow probabilities, and correlations between the two (Tables 1 and 2).

Table 1. Role of the Mining Sector in the National Economy (\%, 2003-2011)

\begin{tabular}{lccccccccc}
\hline Year & 20 & 200 & 20 & 20 & 20 & 20 & 20 & 20 & 20 \\
& 03 & 4 & 05 & 06 & 07 & 08 & 09 & 10 & 11 \\
\hline In GDP & 12 & 17.0 & 16 & 29 & 27 & 20 & 19 & 22 & 20 \\
& .6 & & .6 & .9 & .1 & .2 & .5 & .7 & .2 \\
In manufacturing & 49 & 58.1 & 65 & 69 & 63 & 56 & 60 & 66 & 69 \\
& .6 & 5 & .9 & .9 & .4 & .4 & .9 & .7 & .6 \\
In exports & 57 & 70.8 & 75 & 75 & 80 & 80 & 84 & 87 & 89 \\
& .6 & & .8 & .7 & .7 & .7 & .6 & .8 & .2 \\
\hline
\end{tabular}

Table 2. Investment and Production in the Mining Sector (Billions MNT)

\begin{tabular}{lcclllllll}
\hline Year & 20 & 200 & 200 & 200 & 200 & 200 & 200 & 201 & 201 \\
& 03 & 4 & 5 & 6 & 7 & 8 & 9 & 0 & 1 \\
\hline Investment & 33 & 53 & 82 & 126. & 436. & 502. & 750. & 294 & 158 \\
& & & & 1 & 8 & 5 & 9 & 0 & 9 \\
Production & 37 & 635. & 790. & 678. & 126 & 158 & 149 & 263 & 306 \\
& 8.4 & 1 & 6 & 3 & 8.9 & 3.2 & 6.2 & 3.2 & 1.4 \\
\hline
\end{tabular}

Tax and royalty revenues from the mining sector accounted for most of the total government mining revenue generated from corporate income taxes and royalty fees for the use of environmental resources. The royalty for gold was set at $7.5 \%$. The government mining sector's total revenue has been estimated to grow at $10.4 \%$ per annum in the medium term (Table 3). 
Table 3. Government Mining Revenue Projection (Billions of MNT)

\begin{tabular}{cccrrrr}
\hline Year & $\begin{array}{c}\text { Compan } \\
\text { y Tax }\end{array}$ & Royalty & $\begin{array}{r}\text { Total } \\
\text { mining } \\
\text { revenue }\end{array}$ & $\begin{array}{r}\text { Tax } \\
\text { rev. as \% } \\
\text { of GDP }\end{array}$ & $\begin{array}{r}\text { Royalty } \\
\text { rev. of } \% \\
\text { GDP }\end{array}$ & $\begin{array}{r}\text { Total } \\
\text { rev. as \% } \\
\text { of GDP }\end{array}$ \\
\hline 2002 & 16.2 & 8.3 & 24.5 & 1.3 & 0.7 & 2.0 \\
2003 & 23.5 & 9.7 & 33.2 & 1.7 & 0.7 & 2.4 \\
2004 & 20.0 & 14.5 & 34.5 & 1.3 & 1.0 & 2.3 \\
2005 & 20.9 & 14.7 & 35.6 & 1.2 & 0.9 & 2.1 \\
2006 & 24.8 & 14.6 & 39.4 & 1.3 & 0.8 & 2.1 \\
2007 & 29.8 & 17.0 & 46.8 & 1.4 & 0.8 & 2.3 \\
2008 & 29.9 & 19.4 & 49.3 & 1.3 & 0.9 & 2.1 \\
Annual & $9.0 \%$ & $13.1 \%$ & $10.4 \%$ & & & \\
Growth & & & & & & \\
\hline
\end{tabular}

In 2001, the mining sector accounted for approximately $9 \%$ of tax revenues. Three large mining companies confined to three minerals (gold, copper, and molybdenum) accounted for $95 \%$ of all taxes paid by the mining sector in 2001 . The experience in many mining communities around the world has been that there is often a gap between a community's expectation of a mining enterprise and the enterprise's capacity to deliver that expectation. Mongolia's mining tax system includes corporate taxes, personal income taxes, mineral royalties, value-added taxes, customs and excise duties, social insurance, and stability arrangements. The 1997 Minerals Law requires the Ministry of Finance to implement regulations to govern the income of mining enterprises. The purchase of imported goods is subject to a 15\% VAT. Although mining companies that export their production can receive refunds on taxes paid for imports of production equipment, the government has proposed amending the VAT law to exclude non-producing companies, which would effectively deny VAT refunds to companies during exploration and development phases, increasing the cost of doing business in Mongolia

The government share in Table 4 shows the amount of taxes collected by the government as a percentage. Although Canada's government share is relatively high, a substantial portion of the Canadian tax is collected during later phases of mining. Canada is not as heavily impacted by higher tax rates as Mongolia, which has identified mining as a priority industry for contributing to future growth in its economy and tax revenues.

Table 4. Amounts of Taxes Collected by Country

\begin{tabular}{ccc}
\hline Country & $\begin{array}{c}\text { IRR } \\
(\boldsymbol{\%})\end{array}$ & Government share (\%) \\
\hline Chile & 18.3 & 16.7 \\
Mongolia & 17.2 & 32.8 \\
Papua New & 16.9 & 38.6 \\
Guinea & & \\
Canada & 16.4 & 41.7 \\
Indonesia & 15.0 & 39.7 \\
\hline
\end{tabular}




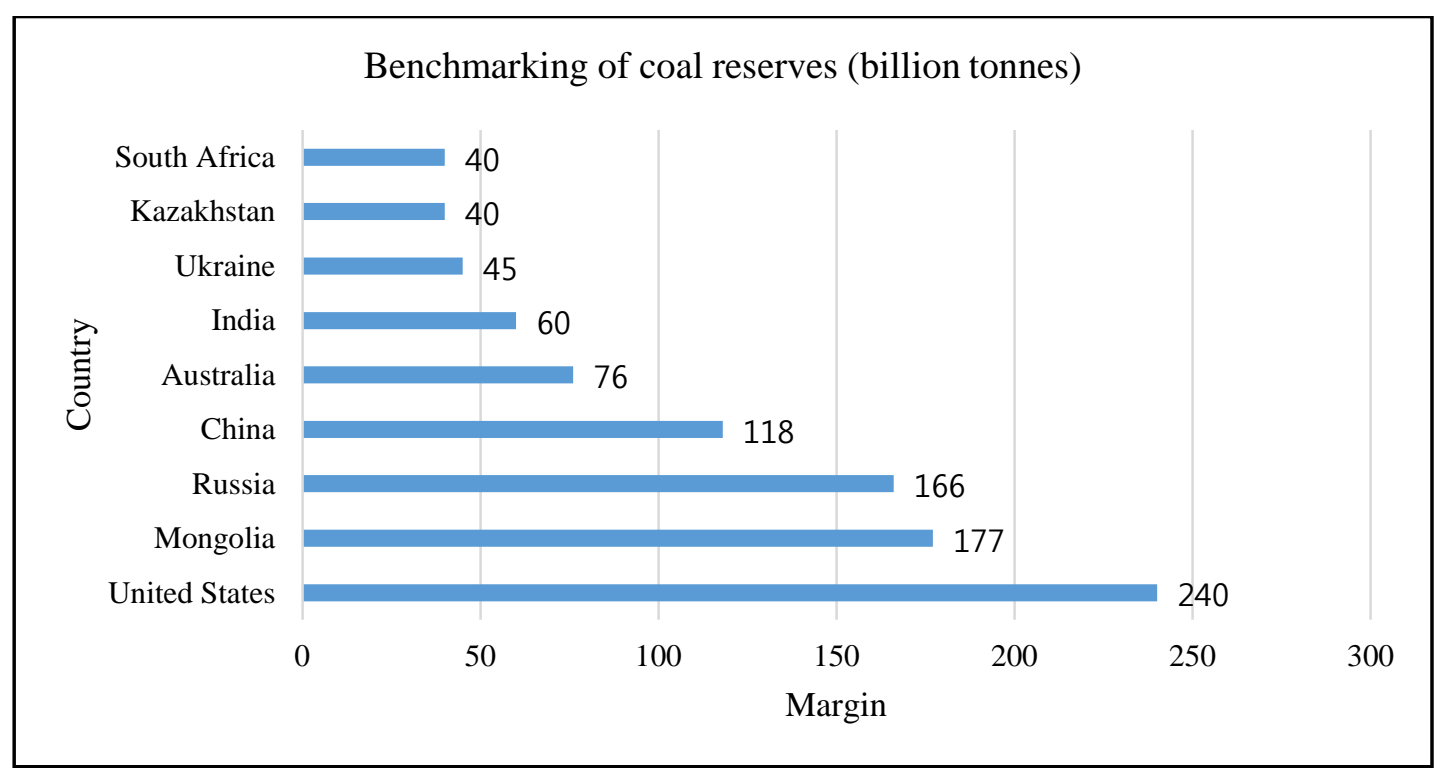

\section{FDI in the Mongolian Mining Sector}

Since the transition to a market economy in the 1990s, Mongolia has received substantial amounts of FDI annually. This inflow started its sharp increase when the Mongolian government opened its mining sector to foreign investment, which helped increase Mongolia's profile as an investment destination. As a result of the mining boom, the FDI inflow grew by almost 19 times in the last two decades (Figure 1).

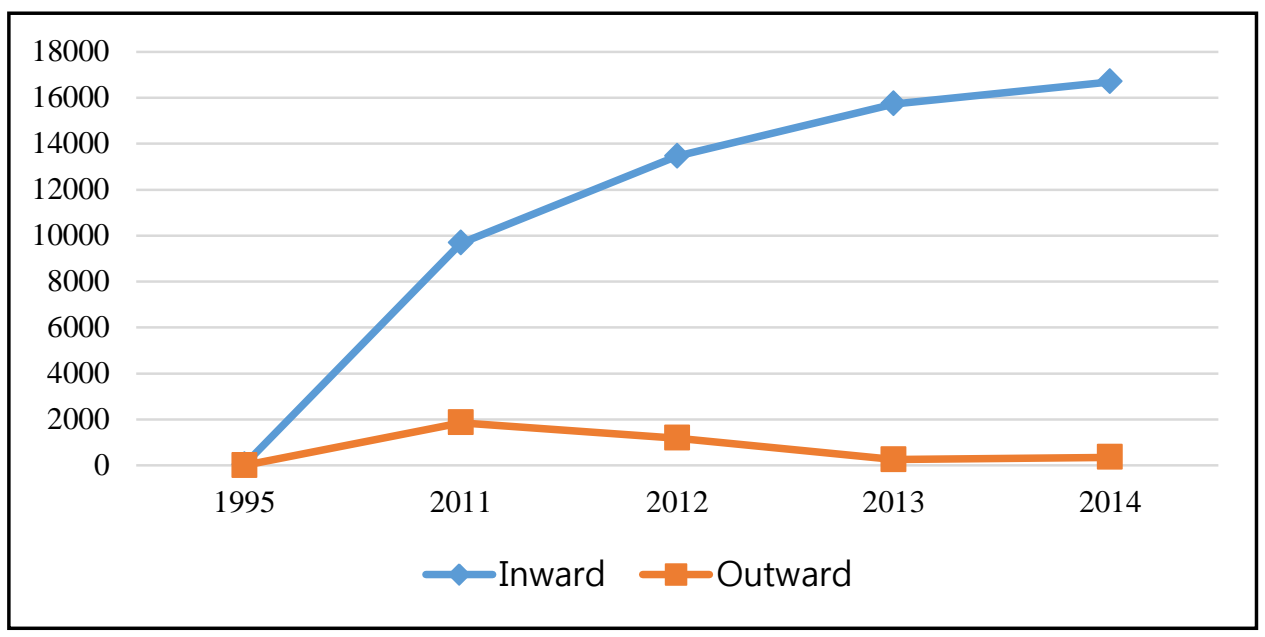

Figure 1. FDI Flow in Mongolia (Million \$), 1995-2014 


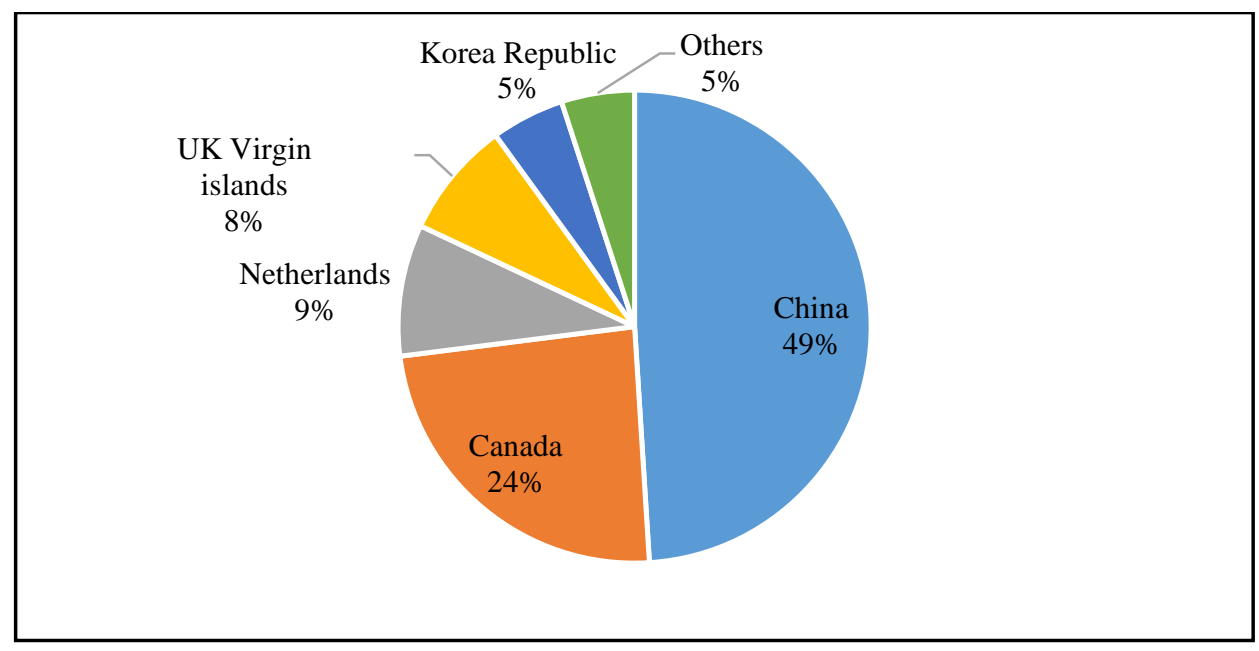

Figure 2. FDI Inflow by Country (1995-2012)

The Mongolian economy was hit hard by an international economic and financial crisis. The economy of the country fell by $26 \%$ in 2009 , which far exceeds the average for the East Asian region (16\%). The FDI inflow quickly recovered in 2010, growing phenomenally by more than $170 \%$ and far exceeding the $24 \%$ average for East Asia to reach the record level of $\$ 4.7$ billion in 2011. In terms of the FDI inflow based on the country of origin, China was by far the largest source of the FDI inflow to Mongolia (49\% in 1900-2012), followed by Canada, the Netherlands, and Luxemburg, in that order. About 140 Singaporean and 100 Canadian companies were registered in Mongolia. Canadian enterprises were mainly in mining and related industries (Figure 2)

Mining companies accounted for 56\% of aggregate FDI, followed by companies in banking, textiles, beverages, telecommunications, and tourism, in that order. A majority of these investments were in joint ventures such as Oyutolgoi, the largest copper-gold joint venture between Mongolia and the Netherlands (Table 5).

Table 5. Top Five Investor Entities in the Mining Sector

\begin{tabular}{|c|c|c|c|c|}
\hline Mine & Entity & Foreign & $\begin{array}{l}\text { Domes } \\
\text { tic }\end{array}$ & Countries \\
\hline Oyutolgoi & 65.005 .920 & $\begin{array}{l}65.005 .91 \\
3\end{array}$ & - & $\begin{array}{l}\text { Mongolia- } \\
\text { Netherlands }\end{array}$ \\
\hline Mcs Mining & 25.100 .000 & $\begin{array}{c}25.000 .00 \\
0\end{array}$ & - & Singapore \\
\hline Gyantbaylag & 7.000 .000 & 7.000 .000 & - & $\begin{array}{r}\text { United } \\
\text { Kingdom }\end{array}$ \\
\hline EAM Bayan-Ulgii & 3.548 .107 & 3.548 .107 & & Canada \\
\hline Tethys Mining & 26.992 .495 & 2.793 .974 & - & Switzerland \\
\hline
\end{tabular}

\section{FDI Inflow Into Mongolia}

Over two decades ago, Mongolia peacefully transitioned from communism to democracy, leaving its centrally planned economy and single-party authoritarian system for a free-market economy and a multiparty parliamentary system. In recent years, Mongolia has taken crucial steps forward in establishing a more modern and vibrant economy, with a booming mining sector driving its double-digit economic growth. Driving this growth is a booming mining sector in which Mongolia holds key deposits in copper, gold, coking coal, and uranium, which together are valued at more than $\$ 1.2$ trillion. Mongolia has a major competitive advantage in being located next to China, the 
largest commodity consumer in the world. However, given that more than $90 \%$ of the landlocked country's exports go to China, the Mongolian economy is currently heavily dependent on China's growth. The Mongolian government aims to transform Mongolia into an export-oriented and knowledge-based economy by focusing on exploiting strategic minerals, reducing the urban-rural gap, and fostering a balanced ecosystem. Infrastructure systems, including transportation and communications, remain underdeveloped. Mongolia's main economic activities include mining, agriculture, services, and clothing, especially cashmere products and food products. Copper, gold, and cashmere account for about three-quarters of all exports.

There are over 140 registered mining projects in Mongolia, and the sector is dominated by main players such as Tavan Tolgoi (coal producer), Oyu Tolgoi (gold and copper), and Erdenet (copper and molybdenum). The top five gold-mining companies accounted for $81 \%$ of the total output in 2014. The Mongolian government hopes these trends would continue to facilitate Mongolia's economic growth. The most underdeveloped mining sectors include coal mining, copper mining, gold mining, and other mining sectors.

The most recent data are collected under the recently passed Investment Law of Mongolia (IL). The law required all foreign investors to submit their certificates for the calendar year 2014 for new certificates, which may lead to different ways to account for FDI in Mongolia (Table 6). In assessing the international competitiveness of Mongolia's tax regime, it is helpful to undertake both qualitative and quantitative analyses of the tax regime. An internationally competitive mineral taxation regime should encourage the profitable exploitation of as many deposits as possible by recognizing their specific characteristics, provide for the fair participation of mining enterprises, and be stable and transparent over time.

Table 6. Top 10 Investor Countries (Thousand \$, 2008-2013)

\begin{tabular}{ccc}
\hline Country & $\%$ & Total \\
\hline Netherlands & 29.96 & $4,225,300$ \\
China & 26.65 & $3,757,607$ \\
Luxemburg & 8.17 & $1,151,702$ \\
UK Virgin & 7.87 & $1,109,543$ \\
Islands & & \\
Singapore & 5.14 & 724,852 \\
Canada & 3.53 & 498,057 \\
South Korea & 2.69 & 379,267 \\
USA & 2.19 & 308,230 \\
Russia & 2.11 & 297,674 \\
Australia & 1.84 & 260,026 \\
\hline
\end{tabular}

\section{Impacts of FDI on the Mongolian Economy}

FDI has turned mining into a competitive and modern industry and created the possibility to expand into areas in both upstream and downstream industries. Investment in the mining sector has also served as an anchor for large-scale infrastructure projects, especially in railroads and electricity. Mining is usually burdened with royalties and other taxes in Mongolia. Fiscal revenues from mining and imports are substantial and represent an important factor expanding the country's mining output. Fiscal revenues from mining can be used to increase public investment in areas such as health care, education, and infrastructure systems such as roads and rural electrification. Well-managed fiscal revenues from an increase in the mining output may result in production factors.

Mining increases exports sharply because minerals and metals are largely sold in international markets. This provides the foreign currency to increase imports of goods and services. This expansion in exports and the economy's capital stock usually takes place 
through the appreciation of the exchange rate. This does not weaken the international competitiveness of agriculture and manufacturing. An increase in the foreign currency also facilitates the acquisition of expertise and technologies from abroad, improving productivity. Increased mining production augments the income of mining companies and their employees. The income generated in the expansion of mining production comes along with the chain of goods and services in the economy, and this depends partially on the level of unemployment or underemployment.

\subsection{Direct Impacts}

FDI is a key source of capital in Mongolia. In particular, FDI in mining is expected to bring large amounts of capital, and the Mongolian government plans to finance ambitious projects partly from the revenue generated by that investment. FDI has had a significant direct impact on fiscal revenues. Companies with foreign investment have contributed well over $\$ 4$ billion in tax revenue in the past 15 years. During the 2011-2012 mining boom, Mongolia's tax revenue exceeded MNT 2 billion or $48 \%$ of the total tax revenue per year.

In terms of employment generation, by the end of 2012, companies with foreign investment employed 59,000 people (roughly $7.7 \%$ of total employment in the country). However, with the entrance of more foreign companies, the demand for skilled labor has outpaced supply. There is evidence that large mining companies are absorbing most of the english-speaking talent in the labor market by offering higher wages.

FDI has had a major impact in changing Mongolian trade. Copper, coal, and other mineral exports have grown and are expected to grow even further through the opening of large mines in the future. Foreign companies have also contributed to the increase of industrial and capital goods. FDI has impacted Mongolia's infrastructure development. Russia's investment has helped Mongolia build a railway system, and FDI in telecommunications has expanded the country's mobile telephony coverage and internet connections. Mining companies have contributed to the development of local communities by supporting their infrastructure and economic development projects.

\subsection{Indirect Impacts}

An increase in the mining output can impact economic growth indirectly by affecting production factors accumulation and total factor productivity. This indirect impact can result from the quantity and quality of fiscal expenditures, goods and services more efficiently traded abroad, or multiplier effects of expanding income on the economy.

Indirect impacts of FDI include technology transfer and spillovers in the mining sector. FDI in mining has introduced the latest technologies to Mongolia, and mining-related services have brought in world-class equipment suppliers and mining consulting services. FDI in telecommunications has brought modern technologies to the ICT industry, and FDI in services such as accounting and tourism has introduced international standards and management know-how, which can be used across the country for further economic growth.

\section{Acknowledgments}

This research was supported by the Daegu University Research Grant 2015.

\section{References}

[1] C. Jiaojin, "An Empirical Study of the Improvement of the Product Supply Chains in Terms of Reducing Environmental Pollution in China”, IJUNESST, vol. 8, no. 10, (2015), pp. 169-178.

[2] E. Mungunzul and T. Chang, "The Impacts of Foreign Direct Investment on Mining Sector in Mongolia”, Advanced Science and Technology Letters, vol. 114, (2015), pp. 66-71. 
[3] J. Gowen and B. Baatar, "Mining and Petroleum Sector Profile", A Report prepared for the World Bank Group, (2002).

[4] G. Robin and W. Murray, "Overview of Artisanal Mining in Mongolia", A Report prepared for the World Bank, (2003).

[5] International Monetary Fund, Foreign Direct Investment, (2004).

[6] Mongolia Mining Corporation, Interim Report, (2015).

[7] Mongolian National Chamber of Commerce and Industry, Business and Investment Guide, (2014).

[8] Monthly Report, Mineral Resources Authority of Mongolia, September (2015).

[9] National Statistical Office of Mongolia, Country Report of Mongolia, (2004).

[10] National Statistical Office of Mongolia, Statistical Bulletin of Mongolia 2003, (2004)

[11] OECD, Benchmark Definition of Foreign Direct Investment, (2008).

[12] UNCTAD, World Investment Report, New York: United Nations, (2015).

[13] US Department of State, Mongolia Investment Climate Statement, June (2015).

[14] World Bank, Mongolia Mining Sector Managing the Future, Spring (2003).

[15] http://www.mram.gov.mn/images/stories/mram/statistek/2015/monthly_report_2015.09.24.pdf. 
International Journal of $u-$ and e- Service, Science and Technology Vol.9, No. 3 (2016) 